Egyptian Journal of Aquatic Biology \& Fisheries

Zoology Department, Faculty of Science,

Ain Shams University, Cairo, Egypt.

ISSN $1110-6131$

Vol. 22(5): 461 - 474 (2018)

www.ejabf.journals.ekb.eg

\title{
Evaluation of Water Quality and Plankton for Mahmoudia Canal in Northern West of Egypt
}

\author{
Mohamed M. M. El-Feky ${ }^{1}$; Ahmed E. Alprol ${ }^{1 *}$; Ahmed M. M. Heneash ${ }^{1}$; Hamdy \\ A. Abo-Taleb ${ }^{2}$ and Mohsen Y. Omer ${ }^{1}$ \\ 1- National Institute of Oceanography and Fisheries, Egypt. \\ 2- Faculty of Science, Al-Azhar University, Egypt. \\ * Corresponding Author: ah831992@gmail.com
}

\section{ARTICLE INFO \\ Article History: \\ Received: Oct. 20, 2018 \\ Accepted: Dec. 22, 2018 \\ Online: Jan. 2019}

Keywords:

Mahmoudia canal

Water quality

Physical properties

Phytoplankton

Zooplankton

\begin{abstract}
Water quality describes the condition of the water, including chemical, physical, and biological characteristics, usually with regarding to its suitability for a particular purpose. The present study describes the environmental conditions of Mahmoudia canal which are the main water source for Alexandria and Behiera governorates. Water samples were collected from ten sites along the Mahmoudia canal in the year 2018 for study the seasonal variations of the water quality parameters (physicochemical and biological parameters). The measured physicochemical parameters include; (Turbidity, Temperature, $\mathrm{pH}$, Electrical Conductivity, Total Dissolved Solids, Total Suspended Solids, Total alkalinity, Total Hardness, Nitrate, Nitrite, Ammonia, Sulfate, Phosphate, Dissolved Oxygen, Biological Oxygen Demand, Chemical Oxygen Demand, Chlorinated pesticides and some heavy metals). Phytoplankton and Zooplankton were examined as biological parameters. The values of average water quality index (WQI) of Mahmoudia canal ranged from 75.01 (poor water quality) to 132.57 (very poor water quality). According to the results of Cluster analysis, six statistically significant clusters were formed. Three groups of phytoplankton were recorded which, the annual maximum density of phytoplankton recorded in Town of Abou Hommos, while the lowest recorded in site Zawyet Ghazal Village. The highest density registered in winter $(3460.2$ $\mathrm{U} / \mathrm{ml})$, while the lowest density recorded in summer $(831.6 \mathrm{U} / \mathrm{ml})$. In addition to six zooplankton groups were quantified in the analysis of the samples from ten sites, the highest density listed in summer $\left(6000 \mathrm{ind} . / \mathrm{m}^{3}\right)$ ,although the lowest listed in winter (3200 ind./ $\left./ \mathrm{m}^{3}\right)$.
\end{abstract}

\section{INTRODUCTION}

Water is super abundant on the planet as a whole, but fresh potable water is not always available at the right time or the right place for human or ecosystem use. Water quality refers to the physical, chemical and biological characteristics of water. It is a measure of the condition of water relative to the requirements of one or more biotic species and or to any human need or purpose. Rivers are vital and vulnerable freshwater ecosystems that are critical for the sustenance of all life. Rivers are waterways of strategic importance across the world, providing main water resources 
for domestic, industrial and agricultural purposes (Aggarwal and Arora, 2012). Degradation of water quality is a major issue in Egypt.

In spite of the Egyptian Environmental Affairs Agency (EEAA) and the ministry of the environmental protection legislation's, some institutions and drains still discharge their pollutants into the river Nile. These pollutants adversely change the environment in the river by changing the growth rate of species and interfere with the food chain or with public health (Shaaban et al., 2004). Spearman Rank correlation analyses were performed on environmental parameters and zooplankton groups to examine significant relationships. Application of the WQI is also suggested as a very helpful tool that enables the public and decision makers to estimate water quality of fish farms (Heneash, 2015). Salinity, dissolved oxygen and $\mathrm{pH}$ may be responsible for the variations in zooplankton community structure (Heneash et al., 2015).

The severity of present water quality problems in Egypt varies among different water bodies depending on: flow, use pattern, population density, the extent of industrialization, availability of sanitation systems and the social and economic conditions existing in the area of the water source. Discharge of untreated or partially treated industrial and domestic wastewater, leaching of pesticides and residues of fertilizers; and navigation are often factors that affect the quality of water (EEAA, 2002). Mahmoudia canal can be readily contaminated by human activity without any obvious signs. The constituents of concern in domestic and municipal wastewater are pathogens, parasites, nutrients, Oxygen demanding compounds and suspended solids. In Greater Cairo and other cities, the sewerage systems also serve industrial and commercial activities. As these toxic substances (heavy metals, persistent, organic micro pollutants and abundant) are mainly attached to the suspended material, most of it collects in the sludge that can accumulate in aquatic habitats and their concentration increases through biomagnification. Improper sludge disposal or reuse may lead to contamination of surface and ground water (EEAA, 2002). Few studies were published about Mahmoudia canal, (Abdullah and Hussona, 2014) showed that the main water quality is exhibit high pollution levels that create health risks at present, indicates unsafe levels of pollution for direct use in drinking water, irrigation and fisheries.

Therefore, the present study was carried out to monitor the changes in water quality at ten sites in Mahmoudia canal, Egypt, which are a useful source of information for the understanding of seasonal and relationship between physical, chemical and biological changes in Aquatic environments in Mahmoudia canal water quality that it is the main water sources for Alexandria city.

\section{MATERIALS AND METHODS}

\section{Study area}

Mahmoudia canal locates at northern west of Egypt at the northern edge of the Beheira Governorate (receive about $15 \mathrm{Mm}^{3} /$ day). It receives water from the Rosetta branch in Mahmoudia city at km 194.200 with actual served area of 130,200 hectares. (Abo Kila, 2012).

The total length of the canal is $77.170 \mathrm{~km}$ and there are seventy canals off-take from this canal. Al-Mahmoudia canal has three sources of water; two fresh water sources which are from Rosetta branch via El-Atf pump stations at the head of the canal, and Al-Khandaq Eastern canal at km 13.200 on Al-Mahmoudia canal, the third is drainage water from Zarkon drain at $\mathrm{km} 8.500$ on Al-Mahmoudia canal via Edko irrigation pump station which lifting part of Zarkon drain water into Al-Mahmoudia 
canal. The canal receives domestic and agriculture wastes from Zarkon drain and other non-point sources.

\section{Sampling, measuring and analysis}

Water samples were collected seasonally through winter, spring, summer and autumn of 2018. Ten stations were chosen represented different environments of the canal for the present study. The locations description of the sampling stations is shown in Figure (1).

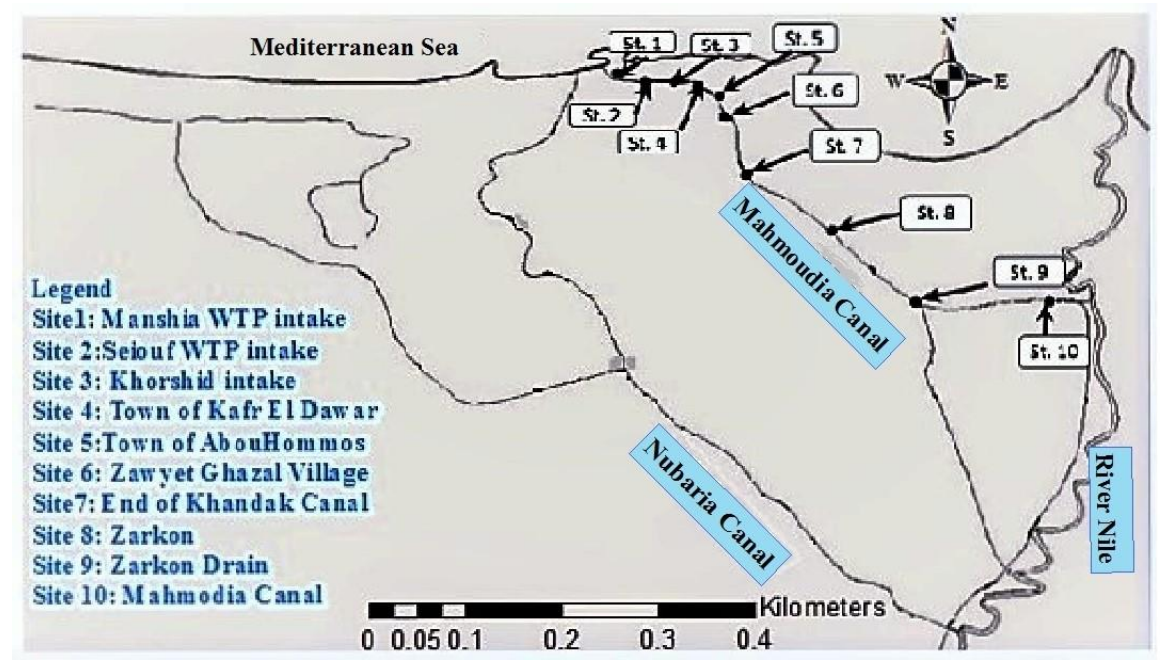

Fig. 1: Location map of Al-Mahmoudia canal and sampling sites.

\section{Physicochemical analysis}

Measuring and analysis were done upon physical, chemical, microbiological parameters. These parameters were measured seasonally (Table 1). Temperature and $\mathrm{pH}$ parameters were estimated at the spot immediately after the collection of the samples. Analyses of water samples were performed using standard analytical methods according to procedures outlined in the standard methods for (APHA, 2005).

Table 1: Measuring methods of physical and chemical parameters.

\begin{tabular}{|c|c|c|c|}
\hline Parameter & Symbol & Units & Test Method \\
\hline pH & & & Digital electrode $\mathrm{pH}$ meter \\
\hline Turbidity & Turb. & NTU & Nephelometer \\
\hline Temperature & $\mathrm{T}$ & & an analytical thermometer \\
\hline Electrical Conductivity at $25^{\circ} \mathrm{C}$ & EC & $\mu \mathrm{S} / \mathrm{cm}$ & Digital conductivity meter \\
\hline Biochemical Oxygen Demand & BOD & $\mathrm{mg} / \mathrm{l}$ & $\begin{array}{l}\text { Azide modification of winkler's titration } \\
\text { method and determined by using } 5 \text { days method }\end{array}$ \\
\hline Chemical Oxygen Demand & COD & $\mathrm{mg} / \mathrm{l}$ & Reflux titrimetry method \\
\hline Total Dissolved Solids at $\mathbf{1 0 5}^{\circ} \mathrm{C}$ & TDS & $\mathrm{mg} / \mathrm{l}$ & $\begin{array}{l}\text { filtration a volume of sample with glass micro } \\
\text { fiber filter (GF/C) and a known volume of filtrate was evaporated }\end{array}$ \\
\hline Total Suspended Solids & TSS & $\mathrm{mg} / \mathrm{l}$ & Membrane filteration method \\
\hline Total Hardness & $\mathrm{TH}$ & $\mathrm{mg} / \mathrm{l}$ & $\begin{array}{l}\text { EDTA complexometric titration method using Erichrome } \\
\text { black-T dye as indicator }\end{array}$ \\
\hline Total Alkalinity & T Alk. & $\mathrm{mg} / \mathrm{l}$ & $\begin{array}{l}\text { by titration with standard sulphuric acid using } \\
\text { phenolphthalein and methyl orange as indicator }(\mathrm{pH}=4.5)\end{array}$ \\
\hline Nitrate & NO3 & $\mathrm{mg} / \mathrm{l}$ & Acid treatment followed by spectrophotometry \\
\hline Nitrite & $\mathrm{NO} 2$ & $\mathrm{mg} / \mathrm{l}$ & \\
\hline Ammonia & HH3 & $\mathrm{mg} / \mathrm{l}$ & Distillation titrimetric method \\
\hline Chloride & $\mathrm{Cl}$ & $\mathrm{mg} / \mathrm{l}$ & Argentometric titration \\
\hline Sulphate & $\mathrm{SO} 4$ & $\mathrm{mg} / \mathrm{l}$ & Turbidimetric methods \\
\hline Phosphate & PO4 & $\mathrm{mg} / \mathrm{l}$ & Ascorbic acid spectrophotometry \\
\hline Pesticides & & & $\begin{array}{l}\text { Chromatographic techniques ( EPA 508.1, } 537 . \\
1 \text { and } 508.1 \text { methods) }\end{array}$ \\
\hline
\end{tabular}




\section{Bacteriological and Biological analysis}

Samples for bacteriological analyses were collected into sterilized plain glass bottles. The most accurate measurements of water quality are made on-site because water exists in equilibrium with its surroundings. The samples were kept in ice on the field and after that refrigerated in the laboratory. Total coliform (TC, CFU/100ml) and fecal coliform (FC, CFU/100ml) were carried out according to standard methods for water and wastewater (APHA, 2005). Water samples were collected using a Rüttiner bottle, and estimation of the phytoplankton standing crop was carried out by sedimentation method as reported in a standard method in American Public Health Association (APHA, 1999), the samples were preserved in a solution of $4 \%$ formaldehyde. Phytoplankton samples were examined in the laboratory using a Research microscope, identification to species and counting will do, the species counts were expressed as unit's $1^{-1}$.

The zooplankton samples were collected by filtering 50 liters of water through a small standard plankton net (mesh size $55 \mu \mathrm{m}$ ) using a plastic container of liters' capacity. The collected samples were preserved directly with $4 \%$ neutral formalin solution in $250 \mathrm{ml}$ polyethylene bottles. The volume of each sample was concentrated to $100 \mathrm{ml}$ and the whole sample was examined in a Petri dish under a research binocular microscope. For zooplankton enumeration purposes, at least two aliquots (2 $\mathrm{ml}$ of well-shaken suspension) were withdrawn from each sample using a graduated pipette, placed in a counting chamber and the number of individuals of each species was counted. The average number of duplicated amination for each sample was estimated and the counts were expressed as number of individuals per cubic meter (Heneash, 2015).

\section{Water Quality Index (WQI)}

WQI is a mathematical approach to summarize multiple properties into a single value. WQI is defined as a rating reflecting the composite influence of different water quality parameters on the overall quality of water. The WQI was computed through three steps. First, each of the 12 parameters (Turbidity, pH, TDS, COD, BOD, total hardness, total alkalinity $\mathrm{Cl}, \mathrm{NO}_{3}, \mathrm{NO}_{2}, \mathrm{SO}_{4}$ ) was assigned a weight (wi) according to its relative importance in the overall quality of water for drinking purposes (Table 2). The maximum weight 5 was assigned to $\mathrm{pH}$, COD and nitrate because of its major importance in water quality assessment; other parameters were assigned weights between 1 and 5 based on their relative significance in the water quality evaluation. Second, the relative weight (Wi) of the chemical parameter was computed using the following equation. $\mathbf{W i}=\mathbf{W i} / \sum_{i=\mathbf{1}}^{n} \mathbf{w i}$

Where: Wi is the relative weight, wi is the weight of each parameter, and $\mathrm{n}$ is the number of parameters. Calculated relative weight (Wi) values of each parameter are given in Table (2). In the third step, a quality rating scale $\left(\mathrm{q}_{\mathrm{i}}\right)$ for each parameter is assigned by dividing it's the concentration in each water sample by its respective standard according to guidelines (EWQS, 2007), and the result is multiplied by 100 :

$$
\mathrm{q}_{\mathbf{i}}=(\mathbf{C i} / \mathrm{Si}) * \mathbf{1 0 0}
$$

Where: $q_{i}$ is the quality rating, $C_{i}$ is the concentration of each chemical parameter in each water sample in $\mathrm{mg} / \mathrm{L}$, and $S_{i}$ is the Egyptian drinking water standard for each chemical parameter in $\mathrm{mg} / \mathrm{L}$. For computing WQI, the sub index (SI) is first determined for each chemical parameter, as given below: $\mathrm{SI}_{\mathrm{i}}=\mathrm{Wi} \times \mathrm{q}_{\mathrm{i}}$ $\mathrm{WQI}=\sum$ SIi-n ; Where: $\mathrm{SI}_{\mathrm{i}}$ is the sub index of $\mathrm{I}^{\text {th }}$ parameter; $\mathrm{W}_{\mathrm{i}}$ is relative weight of $\mathrm{I}^{\text {th }}$ parameter; qi is the rating based on concentration of $\mathrm{I}^{\text {th }}$ parameter, and $\mathrm{n}$ is the number of chemical parameters. The standard allows able value $(\mathrm{Si})$ for each parameter was taken from two criteria Egyptian drinking water quality standards, (EWQS, 2007). The 
computed WQI values are classified into five categories: Excellent water (WQI < 50); good water (WQI=50-100); poor water (WQI=100-200); very poor water (WQI=200300); and water unsuitable for drinking (WQI > 300) (Batabyal and Chakraborty, 2015).

Table 2: Relative weight of chemical parameters.

\begin{tabular}{|l|c|c|c|}
\hline Chemical parameters $^{\text {a }}$ & $\begin{array}{c}\text { Egyptian } \\
\text { Standard }^{\mathbf{b}}\end{array}$ & $\begin{array}{c}\text { Weight } \\
\text { (wi) }\end{array}$ & $\begin{array}{c}\text { Relative } \\
\text { weight (Wi) }\end{array}$ \\
\hline PH & $\mathbf{7 . 5}$ & 5 & 0.108 \\
\hline Turbidity & $\mathbf{1}$ & 4 & 0.086 \\
\hline Total Dissolved solids at $\mathbf{1 0 5}^{\mathbf{0}} \mathbf{C}$ & $\mathbf{1 0 0 0}$ & 4 & 0.086 \\
\hline Ammonia, free & $\mathbf{0 . 5}$ & 4 & 0.086 \\
\hline Chemical Oxygen Demand (COD) & $\mathbf{6}$ & 5 & 0.108 \\
\hline Biologcal Oxygen Demand (BOD) & $\mathbf{1 0}$ & 4 & 0.086 \\
\hline Hardness, Total & $\mathbf{5 0 0}$ & 3 & 0.065 \\
\hline Alkalinity, Total & $\mathbf{1 0 0}$ & 4 & 0.086 \\
\hline Chloride & $\mathbf{2 5 0}$ & 3 & 0.065 \\
\hline Nitrate & $\mathbf{4 5}$ & 2 & 0.043 \\
\hline Nitrite & $\mathbf{0 . 2}$ & 5 & 0.108 \\
\hline Sulphate & $\mathbf{2 5 0}$ & 3 & 0.065 \\
\hline & & $\sum \mathrm{w}_{\mathrm{i}}=46$ & $\sum \mathrm{Wi}=1$ \\
\hline
\end{tabular}

(a) Chemical parameters in $\mathrm{mg} / \mathrm{L}$. (b) Values indicates desirable limit, in absence of alternate source (EWQS, 2007).

\section{Statistical analysis}

Statistical analysis was computed by Microsoft office Excel 2010. Inter relationships between different parameters were determined from the correlation matrix formed in IBM SPSS statistics, ver. 22 program. The correlation coefficients are considered significant at the $95 \%$ confidence level $(\mathrm{p} \leq 0.05)$ and 0.01 levels $(2-$ tailed). Cluster Analysis (CA) was applied to the results by using the MVSP (version 3.1) package program. Cluster analysis was done using Ward's method (ztransformation of the input data, Euclidean distance as similarity measure) based on the standardized mean of 16 measured physicochemical water parameters obtained from the four seasons as Turbidity, $\mathrm{pH}$, EC, TDS, TSS, $\mathrm{NH}_{3}, \mathrm{COD}, \mathrm{BOD}$, hardness, T.Alkalinity, $\mathrm{Cl}, \mathrm{PO}_{4}, \mathrm{NO}_{3}, \mathrm{NO}_{2}, \mathrm{Si}$ and $\mathrm{SO}_{4}$ were used as variables to show the spatial heterogeneity among the stations.

\section{RESULTS AND DISCUSSION}

\section{Physio-chemical and biological parameters}

Seasonal variations of physicochemical and biological parameters of the water samples from the ten sampling sites on the Mahmoudia canal were performed as shown in Table (3).

The present study revealed that, $\mathrm{pH}$ values were slightly higher during the winter compared to the other seasons and it was accompanied by increase in dissolved oxygen. The $\mathrm{pH}$ value of water is controlled by the dissolved oxygen, water temperature, sewage discharge, decomposition of organic matter and photo synthetic activities (Nassar and Hamed, 2003). pH is not only a measure of potential pollutants but also is related to the concentration of many other substances, particularly the weakly dissociated acids and bases (Abdelmongy, and El-Moselhy, 2015).

Electrical conductivity values varied between 443 and $2056 \mu \mathrm{S} / \mathrm{cm}$. It's maximum value recorded in the winter at all sampling sites $11084 \mu \mathrm{S} / \mathrm{cm}$ and the 
minimum value was in the summer in all sampling fields $5085 \mu \mathrm{S} / \mathrm{cm}$ which may be attributed to silts which it brings during its course in the rainy season. The average value of typical, unpolluted rivers is approximately $350 \mu \mathrm{S} / \mathrm{cm}$ (Koning and Roos 1999). Therefore, the parameter does not give cause for concern and it makes the water suitable for direct domestic use.

Table 3: Average of physical, chemical and biological analysis of different stations in the study area.

\begin{tabular}{|c|c|c|c|c|c|c|c|c|c|c|c|c|c|c|c|c|c|c|c|c|}
\hline$\underset{\dot{z}}{\dot{z}}$ & $\dot{E}$ & $\bar{a}$ & 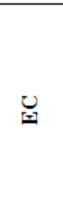 & 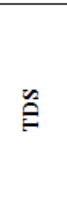 & $\tilde{\omega}$ & $\vec{z}$ & రิ & Оิ & 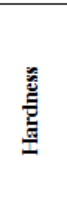 & $\begin{array}{l}\stackrel{y}{ٍ} \\
\dot{-}\end{array}$ & ర & $\stackrel{0}{0}$ & $\stackrel{0}{\mathbf{z}}$ & $\stackrel{\Sigma}{Z}$ & $\bar{\Delta}$ & $\vec{D}$ & 言 & 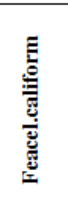 & 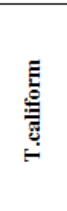 & 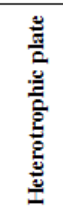 \\
\hline 1 & 9.3 & 7.7 & 624.2 & 628 & 12 & 4.6 & 23.9 & 7.7 & 176.2 & 195 & 60.3 & 0.2 & 5.3 & 0.3 & 2.95 & 61.5 & 20.7 & 250.2 & 5200 & 6200 \\
\hline 2 & 4.4 & 7.7 & 788 & 487.7 & 8.6 & 3 & 25.7 & 10.7 & 218 & 221 & 58.7 & 0.06 & 10.6 & 0.6 & 1.7 & 95.9 & 20 & 153 & 5400 & 10000 \\
\hline 3 & 14.3 & 7.8 & 638 & 625.5 & 12.6 & 3.0 & 19.1 & 17 & 173 & 199 & 58.3 & 0.2 & 5.2 & 0.3 & 3.9 & 70.2 & 20.3 & 601 & 5175 & 6550 \\
\hline 4 & 8.4 & 7.8 & 504 & 413 & 10 & 2.9 & 21 & 3.8 & 163 & 171 & 62.3 & 0.17 & 4.3 & 0.2 & 1.0 & 44.1 & 20.3 & 352 & 10175 & 4400 \\
\hline 5 & 9.6 & 7.8 & 609 & 553 & 10 & 2.4 & 20.7 & 16 & 166 & 187 & 79.3 & 0.1 & 5.6 & 0.4 & 1.8 & 56.6 & 20 & 1167 & 6225 & 16675 \\
\hline 6 & 7.9 & 7.8 & 911 & 359 & 11.3 & 2.3 & 20 & 2.5 & 249 & 209 & 139 & 0.09 & 8.4 & 0.5 & 1.3 & 170.9 & 20 & 1602 & 9500 & 6625 \\
\hline 7 & 6.1 & 7.7 & 776 & 356 & 7.33 & 2.4 & 24 & 9.7 & 181 & 196 & 85 & 0.1 & 7.3 & 0.5 & 2.9 & 128 & 19 & 1700 & 9500 & 19450 \\
\hline 8 & 5.6 & 7 & 988 & 351 & 12 & 2.6 & 36 & 16 & 232 & 210 & 143 & 0.1 & 10 & 0.6 & 3.9 & 355 & 19 & 2475 & 26700 & 64350 \\
\hline 9 & 6.8 & 7.7 & 762 & 451 & 10 & 2.2 & 42 & 9.7 & 182 & 196 & 81.9 & 0.12 & 7.6 & 0.4 & 3.2 & 113 & 20 & 1500 & 8275 & 15000 \\
\hline 10 & 7.1 & 7.6 & 971 & 342 & 12 & 2 & 37 & 12 & 219 & 203 & 135 & 0.06 & 10 & 0.4 & 3.3 & 228 & 59 & 2633 & 5350 & 10425 \\
\hline
\end{tabular}

Turbidity values were ranged from 2.71 to 20.8 NTU. The maximum values were in the winter with 20.8 NTU while the minimum value was 2.71 NTU recorded in the summer. The reason for the recorded higher turbidity in winter season may be due to the mixing of sewage water and high rate of evaporation.

The results of the present study revealed that the maximum value of biological oxygen demand (BOD) was observed in the winter with $69.2 \mathrm{mg} / \mathrm{L}$ and the minimum values in the summer was $0.9 \mathrm{mg} / \mathrm{L}$ in all sampling sites. The highest value of BOD was above $10 \mathrm{mg} / \mathrm{L}$ which showed in some station could be attributed to the abundance of bacterial and microbial activity in these areas and/or the decomposition of organic matter, this agrees with (Abdar, 2013).

Chemical oxygen demand (COD) is a reliable parameter for judging the extent of pollution in water. The highest value was noted $54 \mathrm{mg} / \mathrm{L}$ in autumn season and minimum value was $6.4 \mathrm{mg} / \mathrm{L}$ in the summer season. A trend of increasing COD level show ing the population load and activities caused by the mixing of sewage water, garbage dumping and industrial discharges. This increase in COD indicates that the pollution may increase and hence need exercise of monitoring, abatement and control.

Nutrient salts: Nitrates levels varying from $3.23 \mathrm{mg} / \mathrm{L}$ to $17.99 \mathrm{mg} / \mathrm{L}$ which the lowest nitrate concentration was 5.2 - 8.26 during spring, while the highest nitrate concentrations were recorded during winter at the different sites may be owing to in the winter mixing deepening increased nitrate enrichment into the euphotic zone from deeper water (Al-Qutob et al., 2002), and the lower concentrations during the other seasons may due to high flourishing of phytoplankton observed (Ferrer, 1996).

Concentrations of dissolved nitrite in water in the present study sites ranged from $0.05-1.49 \mathrm{mg} / \mathrm{L}$. The highest nitrite concentrations recorded in the summer, while the lowest concentrations recorded during the autumn season.

Ammonia concentrations ranged from $0.14-8.5 \mathrm{mg} / \mathrm{L}$, the highest ammonia concentration recorded in autumn and spring season in while the lowest concentration recorded during the winter season. Light has an inhibitory effect on ammonium oxidation by nitrifying bacteria (Guerrero and Jones, 1996). Presence of ammonia is an indicator of pollutants of high activity and related to the presence of wastewater treatment plant and industrial discharges near this location. The excess usage of inorganic fertilizers containing nitrogen is the main source of nitrate ions in the water 
sources. Also, the complete oxidation of nitrogen from the decaying of organic materials in the surface water and the sediment is an important factor in producing ammonia, nitrate and nitrite (Taha et al., 2004).

The concentration of available $\mathrm{PO}_{4}^{3-}$ varied from 0.02 to $0.56 \mathrm{mg} / \mathrm{L}$, respectively with higher levels in the summer. Low phosphate concentrations in the examination, may be due to uptake by phytoplankton and primary producers (Al-Qutob et al., 2002).

Anions: The Chloride contents were ranged from 28.6 to $374 \mathrm{mg} / \mathrm{L}$, which chloride content was lower than the accepted limit of $250 \mathrm{mg} / \mathrm{L}$ at the sampling sites in all season of the canal except 6,8 and 10 stations. The levels winter were higher than those obtained in other seasons and the minimum levels were in the summer season. The lowest concentration of chloride was affected more with fresh water from different drains.

Sulfate concentration in the canal varied from 29 to $1227 \mathrm{mg} / \mathrm{L}$. The concentration of $\mathrm{SO}_{4}{ }^{2-}$ was lower in the summer as compared to other seasons and the maximum levels recorded in the winter season which might be contributed by agricultural runoffs. From the observations, it can be seen that sulfate was present under acceptable limits expect in the winter season.

The anions and cations are naturally very variable in surface waters due to climatic and geographical conditions also; their distribution depends on the evaporation rate and the drainage water from different drains (Shama et al., 2011).

Hardness: Total hardness gives information about the concentration of $\mathrm{Ca}$ and $\mathrm{Mg}$ ions. The hardness of the canal water fluctuated between 138.8 and $456.8 \mathrm{mg} / \mathrm{L}$. The trend of variation was non-uniform in all the seasons but it increased in winter season and deceased in summer season.

In the present investigation, total Alkalinity ranged between 158 and $276 \mathrm{mg} / \mathrm{L}$. Alkalinity at all the seasons in all the sites was above the desirable limit prescribed for drinking water which is $120 \mathrm{mg} / \mathrm{L}$ (WHO). The high values of Alkalinity may also be due to an increase in free carbon dioxide in the river which ultimately results in the increase in Alkalinity. High Alkalinity may cause problems if water is used for irrigation purposes as high alkalinity leads to increase in relative proportion of sodium in soil by precipitating $\mathrm{Ca}$ and $\mathrm{Mg}$ ions.

Total dissolved solids and total suspended are common indicators of polluted waters. TDS values ranged from 266 to $1234 \mathrm{mg} / \mathrm{L}$, and the results were high in winter and low in summer. TSS values ranged from 6 to $18 \mathrm{mg} / \mathrm{L}$. The values were low as compared with the (IS) Standards therefore the palatability of water with TDS and TSS can be considered to be good. At all the sites in completely seasons it was observed that the dissolved solid contents were found to be greater than the suspended solid levels may be due to is indicative of erosion that has taken place during the river. Chlorinated Pesticides: The concentration of pesticides such as a- BHC, b- BHC, gBHC (Lindane), d-BHC, Heptachlor, Heptachlor epoxide(isomer), g-Chlordane and Endosulfan I, were undetectable indicating that the canal is free from them and hence safe for drinking purposes. Galal, (1983) reported that Lindane, DDE and DDT were found in Mahmoudia canal and the concentrations were ranged from 0.91 to $2.32 \mu \mathrm{g} / \mathrm{l}$.

Heavy metals: in this study some heavy metals were investigated in the autumn season as shown in Figure (2). Silver (Ag), Boron (B), Berylium (Be), Copper $(\mathrm{Cu})$ and Cadmium $(\mathrm{Cd})$ were undetectable at both the sites, in addition to Nickel $(\mathrm{Ni})$, and Lead $(\mathrm{Pb})$ at most sites therefore the water of canal is free from toxic metals. 


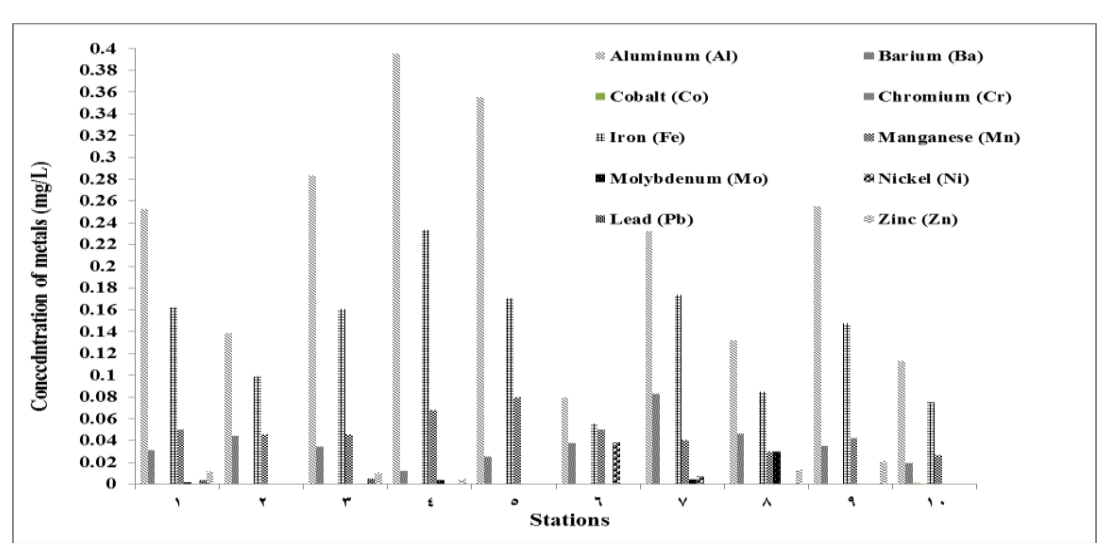

Fig. 2: Concentration of heavy metals in ppm from Mahmoudia canal.

Hence there is no danger with respect to these metals Barium (Ba), Cobalt $(\mathrm{Co})$, Chromium (Cr), Iron (Fe), Manganese (Mn), Molybdenum (Mo), Nickel (Ni), Lead $(\mathrm{Pb})$ and Zinc $(\mathrm{Zn})$ were also below the detection limits.

The concentrations of Aluminum (Al) in the water varied from 0.08 to 0.395 mg/L. Both towns of Kafr El Dawar and Abou Hommos sites exceeded the background level with values 0.395 and $0.355 \mathrm{mg} / \mathrm{L}$, respectively and the WHO limit of $0.2 \mathrm{mg} / \mathrm{L}$. Aluminum being non-toxic presents no health hazards at concentrations normally found in natural waters, but at very high aluminum levels can sometimes cause water to have a bluish color. Galal, (1983) also cited that the heavy metals $(\mathrm{Cu}$, $\mathrm{Pb}, \mathrm{Zn}, \mathrm{Mn}$ and $\mathrm{Fe}$ ) were found in the canal at levels less than the maximum permissible limits.

\section{Biological parameters Phytoplankton:}

Table 4 shows that, the average three groups of phytoplankton. The lowest listed in summer $(831.6 \mathrm{U} / \mathrm{ml})$ because zooplankton feeds on phytoplankton.

Table 4: Seasonal variation of phytoplankton (U/ml) at Al-Mahmodia canal in 2018

\begin{tabular}{|c|c|c|c|c|c|c|c|c|c|c|c|}
\hline \multicolumn{11}{|c|}{ Winter } & \multirow{2}{*}{ Average } \\
\hline & 1 & 2 & 3 & 4 & 5 & 6 & 7 & 8 & 9 & 10 & \\
\hline Phytoplancton & 4185 & 502 & 3761 & 3297 & 13841 & 832 & 1901 & 1731 & 2970 & 1582 & 3460.2 \\
\hline Blue Green Algae & 92 & 61 & 92 & 246 & 366 & 58 & 161 & 358 & 266 & 415 & 211.5 \\
\hline Green Algae & 341 & 51 & 216 & 225 & 929 & 116 & 311 & 440 & 195 & 284 & 310.8 \\
\hline Diatoms & 3553 & 276 & 3395 & 2642 & 12292 & 541 & 1187 & 922 & 2058 & 860 & 2772.6 \\
\hline \multicolumn{12}{|c|}{ Spring } \\
\hline Phytoplancton & 1013 & 1322 & 743 & 2033 & 1962 & 857 & 1107 & 1335 & 2611 & 1660 & 1464.3 \\
\hline Blue Green Algae & 133 & 200 & 44 & 22 & 411 & 121 & 198 & 108 & 294 & 97 & 162.8 \\
\hline Green Algae & 214 & 420 & 133 & 282 & 555 & 267 & 262 & 206 & 403 & 333 & 307.5 \\
\hline Diatoms & 457 & 318 & 330 & 990 & 711 & 515 & 544 & 726 & 992 & 917 & 650 \\
\hline \multicolumn{12}{|c|}{ Summer } \\
\hline Phytoplancton & 983 & 991 & 492 & 1464 & 502 & 664 & 547 & 806 & 1487 & 380 & 831.6 \\
\hline Blue Green Algae & 184 & 265 & 82 & 338 & 90 & 163 & 58 & 64 & 143 & 58 & 144.5 \\
\hline Green Algae & 553 & 380 & 133 & 605 & 260 & 359 & 336 & 512 & 762 & 184 & 408.4 \\
\hline Diatoms & 184 & 173 & 236 & 352 & 125 & 131 & 134 & 205 & 493 & 81 & 211.4 \\
\hline \multicolumn{12}{|c|}{ Autumn } \\
\hline Phytoplancton & 1042 & 1382 & 740 & 2035 & 1962 & 859 & 1107 & 1335 & 2611 & 1669 & 1474.2 \\
\hline Blue Green Algae & 134 & 205 & 33 & 0 & 493 & 70 & 198 & 108 & 294 & 92 & 162.7 \\
\hline Green Algae & 218 & 420 & 133 & 288 & 556 & 268 & 262 & 206 & 403 & 328 & 308.2 \\
\hline Diatoms & 465 & 317 & 333 & 998 & 744 & 514 & 544 & 726 & 992 & 911 & 654.4 \\
\hline \multicolumn{12}{|c|}{ Average } \\
\hline Blue Green Algae & 108.6 & 146.2 & 50.2 & 121.2 & 272 & 82.4 & 123 & 127.6 & 199.4 & 132.4 & 136.3 \\
\hline Green Algae & 331.5 & 317.75 & 153.75 & 350 & 575 & 252.5 & 292.75 & 341 & 440.75 & 282.25 & 333.725 \\
\hline Diatoms & 1164.75 & 271 & 1073.5 & 1245.5 & 3468 & 425.25 & 602.25 & 644.75 & 1133.75 & 692.25 & 1072.1 \\
\hline
\end{tabular}


The annual highest density recorded in site 5 , while the lowest recorded in site 6. The highest density listed in winter $(3460.2 \mathrm{U} / \mathrm{ml})$, while the lowest density recorded in summer $(831.6 \mathrm{U} / \mathrm{ml})$ due to zooplankton feed on phytoplankton. Other hand the diatoms was the largest density of phytoplankton this result agrees with Heneash et al. (2015), while the lowest was Blue Green Algae.

\section{Zooplankton:}

From the analyzed data in Table 5, a visible change in zooplankton community with regard to numerical abundance and composition was evident among sites and in the seasonal cycle. In average, 6 zooplankton groups were quantified through the analysis of the samples collected from ten sites in 4 seasons, the highest density listed in summer $\left(6000\right.$ ind. $\left./ \mathrm{m}^{3}\right)$ this results agree with Aboul Ezz et al. (2014), while the lowest listed in winter (3200 ind. $/ \mathrm{m}^{3}$ ) due to reverse relation between phytoplankton and zooplankton. The annual highest density recorded in sites 4 and 5, while the lowest recorded in site 9. Maybe, these organisms effects by light. The influence of variable light source intensity on the dial vertical migration of the zooplankton continues to be the subject of numerous studies (Martynova and Gordeeva, 2010). Also, a significantly reduced attraction to visible light was noted for the juvenile, Copepoda and Rotifera forms (Springer and Skrzypczak, 2015).

Table 5: seasonal variation of zooplankton (ind./ $\mathbf{m}^{3}$ ) at Al-Mahmodia canal in 2018

\begin{tabular}{|c|c|c|c|c|c|c|c|c|c|c|c|}
\hline \multicolumn{12}{|c|}{ Winter } \\
\hline Groups & 1 & 2 & 3 & 4 & 5 & 6 & 7 & 8 & 9 & 10 & Average \\
\hline Rotifers & 1000 & 1000 & 0 & 1000 & 0 & 1000 & 0 & 1000 & 0 & 1000 & 600 \\
\hline Copepoda & 1000 & 1000 & 1000 & 0 & 1000 & 1000 & 1000 & 0 & 0 & 1000 & 700 \\
\hline Protozoa & 0 & 0 & 0 & 1000 & 1000 & 1000 & 1000 & 0 & 1000 & 0 & 500 \\
\hline Ostracoda & 1000 & 0 & 0 & 1000 & 0 & 0 & 0 & 1000 & 0 & 2000 & 500 \\
\hline Nematoda & 0 & 1000 & 1000 & 0 & 0 & 0 & 0 & 1000 & 1000 & 1000 & 500 \\
\hline Chordate & 0 & 0 & 0 & 2000 & 1000 & 0 & 1000 & 0 & 0 & 0 & 400 \\
\hline Average & 500 & 500 & 333.333 & 833.333 & 500 & 500 & 500 & 500 & 333.333 & 833.333 & 3200 \\
\hline \multicolumn{12}{|c|}{ Spring } \\
\hline Groups & 1 & 2 & 3 & 4 & 5 & 6 & 7 & 8 & 9 & 10 & Average \\
\hline Rotifers & 0 & 2000 & 1000 & 1000 & 2000 & 1000 & 0 & 0 & 1000 & 1000 & 900 \\
\hline Copepoda & 1000 & 0 & 0 & 1000 & 1000 & 1000 & 1000 & 2000 & 0 & 0 & 700 \\
\hline Protozoa & 0 & 1000 & 1000 & 1000 & 1000 & 0 & 2000 & 0 & 0 & 1000 & 700 \\
\hline Ostracoda & 1000 & 1000 & 0 & 2000 & 1000 & 0 & 0 & 2000 & 0 & 1000 & 800 \\
\hline Nematoda & 2000 & 0 & 1000 & 1000 & 2000 & 0 & 0 & 1000 & 0 & 0 & 700 \\
\hline Chordate & 1000 & 0 & 1000 & 0 & 2000 & 1000 & 0 & 1000 & 2000 & 1000 & 900 \\
\hline Average & 833.333 & 666.667 & 666.667 & 1000 & 1500 & 500 & 500 & 1000 & 500 & 666.667 & 783.333 \\
\hline \multicolumn{12}{|c|}{ Summer } \\
\hline Groups & 1 & 2 & 3 & 4 & 5 & 6 & 7 & 8 & 9 & 10 & Average \\
\hline Rotifers & 1000 & 2000 & 2000 & 1000 & 2000 & 2000 & 0 & 1000 & 1000 & 1000 & 1300 \\
\hline Copepoda & 1000 & 1000 & 1000 & 1000 & 1000 & 1000 & 1000 & 0 & 0 & 0 & 700 \\
\hline Protozoa & 0 & 0 & 0 & 2000 & 2000 & 2000 & 3000 & 2000 & 0 & 0 & 1100 \\
\hline Ostracoda & 1000 & 2000 & 2000 & 2000 & 0 & 0 & 0 & 3000 & 0 & 2000 & 1200 \\
\hline Nematoda & 2000 & 2000 & 2000 & 2000 & 0 & 0 & 0 & 1000 & 1000 & 1000 & 1100 \\
\hline Chordate & 0 & 0 & 0 & 2000 & 2000 & 2000 & 0 & 0 & 0 & 0 & 600 \\
\hline Average & 833.333 & 1166.67 & 1166.67 & 1666.67 & 1166.67 & 1166.67 & 666.667 & 1166.67 & 333.333 & 666.667 & 1000 \\
\hline \multicolumn{12}{|c|}{ Autumn } \\
\hline Groups & 1 & 2 & 3 & 4 & 5 & 6 & 7 & 8 & 9 & $\mathbf{1 0}$ & Average \\
\hline Rotifers & 0 & 0 & 0 & 1000 & 2000 & 1000 & 0 & 0 & 1000 & 1000 & 600 \\
\hline Copepoda & 0 & 0 & 0 & 1000 & 1000 & 1000 & 1000 & 0 & 0 & 0 & 400 \\
\hline Protozoa & 0 & 1000 & 1000 & 1000 & 1000 & 0 & 0 & 0 & 0 & 1000 & 500 \\
\hline Ostracoda & 1000 & 1000 & 0 & 2000 & 1000 & 0 & 0 & 2000 & 0 & 1000 & 800 \\
\hline Nematoda & 2000 & 0 & 1000 & 1000 & 2000 & 0 & 0 & 1000 & 0 & 0 & 700 \\
\hline Chordate & 1000 & 2000 & 0 & 1000 & 2000 & 1000 & 0 & 0 & 2000 & 1000 & 1000 \\
\hline Average & 666.667 & 666.667 & 333.333 & 1166.67 & 1500 & 500 & 166.667 & 500 & 500 & 666.667 & 666.667 \\
\hline
\end{tabular}




\section{Water Quality Index}

The results of WQI and water type based on elven parameters are presented in Table (6). The values of average water quality index (WQI) of Mahmoudia canal ranged from 75.01 (poor water quality) to 132.57 (very poor water quality). WQI registered the lowest value at site (4) during summer poor water quality, while other sites were very poor, in addition to maximum value was observed at site (1) during autumn.

The quality of water in summer and winter season is poor, while in autumn and spring season move towards very poor conditions. This may be due to the water quality of which was influenced by organic and inorganic nutrient pollutants. The trend of the aquatic WQI was not clear due to the fluctuating nature of water quality. The discharge of return irrigation water, industrial and municipal wastes into canal water through drains, containing high levels of nutrient salts and heavy metals deteriorate the water quality of canal and accordingly in this period. In winter may dilution from rainy water reduce the activity of microorganisms, increase in oxygen and dilution to wastewater occurs.

Table 6: WQI of Mahmoudia canal at different sampling points.

\begin{tabular}{|c|c|c|c|c|c|c|c|c|c|c|}
\hline \multirow{2}{*}{ Season } & \multicolumn{10}{|c|}{ Site } \\
\cline { 2 - 12 } & $\mathbf{1}$ & $\mathbf{2}$ & $\mathbf{3}$ & $\mathbf{4}$ & $\mathbf{5}$ & $\mathbf{6}$ & $\mathbf{7}$ & $\mathbf{8}$ & $\mathbf{9}$ & $\mathbf{1 0}$ \\
\hline Winter & 40.489 & 111.07 & 126.86 & 99.59 & 36.77 & 40.08 & 74.54 & 175.03 & 102.83 & 131.35 \\
\hline Spring & 210.35 & 102.5 & 160.4 & 96.64 & 156.21 & 139.5 & 122.93 & 124.33 & 145.35 & 129.18 \\
\hline Summer & 55.46 & 18.45 & 43.52 & 8.47 & 50.70 & 56.56 & 46.9 & 90.64 & 57.72 & 82.75 \\
\hline Autumn & 209.24 & 97.06 & 199.52 & 95.37 & 161.44 & 139.49 & 90.46 & 115.75 & 127.96 & 86.06 \\
\hline Average & $\mathbf{1 2 8 . 8 8}$ & $\mathbf{8 2 . 2 7}$ & $\mathbf{1 3 2 . 5 7}$ & $\mathbf{7 5 . 0 1}$ & $\mathbf{1 0 1 . 2 8}$ & $\mathbf{9 3 . 9 0}$ & $\mathbf{8 3 . 7 0}$ & $\mathbf{1 2 6 . 4 4}$ & $\mathbf{1 0 8 . 4 6}$ & $\mathbf{1 0 7 . 3 3}$ \\
\hline
\end{tabular}

\section{Cluster Analysis (spatial similarity and site grouping)}

Cluster analysis is an unsupervised multivariate statistical technique used to classify the objects into clusters based on their similarity and it is one of the most widely used multivariate statistical technique to evaluate the surface water quality and it is typically illustrated by a dendrogram (Tokatlı et al., 2013). Data were then amalgamated into dendrogram plots and the similarity coefficients of all the investigated stations on the Mahmoudia canals base on their water quality similarities are given in Figure (3).

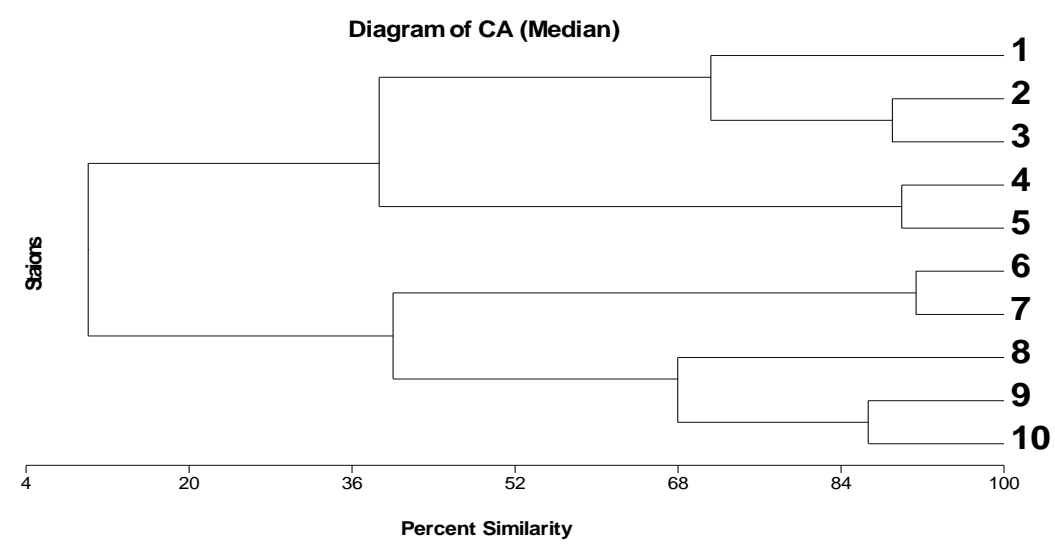

Fig. 3: Dendrogram viewing the relationship amongst sampling locations in Mahmoudia canal. 
According to the results of CA, six statistically significant clusters were formed. Cluster 1 (C1) corresponded to the station 1 was on the canal from Manshia WTP intake. Cluster 2 (C2) comprised stations of 2 and 3 that were on the canal from Seiouf WTP and Khorshid intake represented that site 2 and 3 have the same characteristics, while the cluster 3 (C3) corresponded to the stations of 4, and 5 that were for upstream of the Kafr El Dawar and Abou Hommos city, which have similar

properties. The cluster 4 (C4) consisted from the station of 6 and 7 that related to the irrigation canal for Zawyet Ghazal village and end of Khandak canal and the changes in water quality in them were mainly. Cluster 5 (C5) which is related to station 8 that was close to the input of Zarkon. Cluster 6 (C6) corresponded to the stations of 9 and 10 that were on the irrigation canal of Mahmodia and Zarkon drain and the water quality parameter from this group was similar. It's obvious that group of cluster $\mathrm{C} 1$ to $\mathrm{C} 3$ in addition to $\mathrm{C} 4$ to $\mathrm{C} 6$ were similar characteristics, therefore the differences between the groups indicate the differences in the sources of pollution.

\section{Inter relationships}

From the correlation matrix between various parameters, most of the parameters were found to statistically significant correlation with each other indicating close association of these parameters with each other as presented in Table (7). The conductivity of the water however, showed a highly positive correlation with hardness $(\mathrm{r}=0.884)$, sulfate $(\mathrm{r}=0.889)$ and nitrate $(\mathrm{r}=0.897)$ in addition to the discrepancy observed in the relationship between EC and TDS ( $\mathrm{r}=-0.668)$, nitrite $(\mathrm{r}=0.780)$, total alkalinity $(\mathrm{r}=0.747)$ and chloride $(\mathrm{r}=-0.863)$. This might be attributed to their documented conductibility effect.

Total Alkalinity showed high significant positive relationship with conductivity $(\mathrm{r}=0.747)$, nitrate $(\mathrm{r}=0.822)$, total hardness $(\mathrm{r}=0.785)$ and nitrite $(\mathrm{r}=0.852)$. Total hardness showed high significant positive relationship with Chloride $(\mathrm{r}=0.786)$, conductivity $(\mathrm{r}=0.884)$, total Alkalinity $(\mathrm{r}=0.785)$, nitrite $=0.709)$, nitrate $(\mathrm{r}=0.828)$ and sulfate $(\mathrm{r}=0.741)$. Similar conclusion was drowned out by Shinde et al., (2011). Increasing concentrations of chlorides, mostly sodium chloride, increases Salinity of water. Not unexpectedly chloride concentrations hence, maintained strong correlations with conductivity $(\mathrm{r}=0.863)$, hardness $(\mathrm{r}=0.786)$, nitrate $(\mathrm{r}=0.628)$, TDS $(\mathrm{r}=-0.738)$ and sulfate $(\mathrm{r}=0.864)$.

Statistical analysis showed high positive correlations of nitrate with other several pollution attributes, such as: hardness $(r=0.828)$, EC $(r=0.897)$, sulfate $(r=0.728)$, chloride $(\mathrm{r}=0.862)$, nitrite $(\mathrm{r}=0.842)$, total alkalinity $(\mathrm{r}=0.822)$. These significant correlations indicated the impact of sewage discharge and agricultural runoff. Feacel caliform affected positively with nitrite $(r=0.756)$, nitrate $(r=0.882)$, EC $(r=0.919)$, sulfate $(\mathrm{r}=0.846)$, in addition to that heterotrophic have high positive correlation with total coliform and sulfate $(\mathrm{r}=0.922$ and $\mathrm{r}=0.772$, respectively) at $\mathrm{p}<0.001$. Also, diatom recorded positive correlation with blue green and green algae $(\mathrm{r}=0.772$ and $\mathrm{r}=0.751$, respectively at $\mathrm{p}<0.05)$ while green algae recorded high a significant positive correlation with $\mathrm{pH}(\mathrm{r}=0.960$ at $\mathrm{p}<0.01)$.

The correlations of the Nematoda species were significant through the parameter; $\mathrm{SO}_{4}, \mathrm{NO}_{3}, \mathrm{EC}, \mathrm{Cl}, \mathrm{Si}$ and Feacel Coliform with correlation ( $\mathrm{r}=0.749$, $\mathrm{r}=0.641,0.835, \mathrm{r}=0.681, \mathrm{r}=0.681$ and 0.717$)$ respectively, while protozoa species showed negative correlation with TSS $(\mathrm{r}=-0.668)$. There high negative significant correlation between nitrate and $\mathrm{pH}$ with $(\mathrm{r}=-0.726)$, moreover between phosphate and conductivity $(\mathrm{r}=-0.662)$, Hardness $(\mathrm{r}=-0.696)$, and nitrate $(\mathrm{r}=-0.821)$ in addition to chloride and TDS $(r=-0.738)$, moreover negative correlation was seen between 
Chordate and phytoplankton $(\mathrm{r}=-0.705)$. Feacel caliform affected negatively with ammonia $(r=-0.710)$ and TDS $(r=-0.704)$.

Table 7: Correlation matrix of Mahmoudia canal water parameters.

\begin{tabular}{|c|c|c|c|c|c|c|c|c|c|c|c|c|c|c|c|c|c|}
\hline \multicolumn{18}{|c|}{ Correlations } \\
\hline & 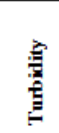 & $\Xi$ & 兑 & $\hat{E}$ & 然 & $\frac{\vec{z}}{z}$ & ప్ & 亏ิ & 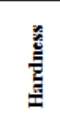 & 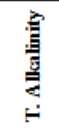 & J & 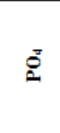 & ż & $\tilde{z}^{\tilde{z}}$ & $\therefore$ & ק్ & $\underline{\underline{E}}$ \\
\hline Turbidity & 1 & & & & & & & & & & & & & & & & \\
\hline$\frac{\mathrm{pH}}{\mathrm{EC}}$ & $\frac{.542}{-539 .}$ & $\frac{1}{-609-}$ & & & & & & & & & & & & & & & \begin{tabular}{|l} 
\\
\end{tabular} \\
\hline Ins & $.673^{\circ}$ & .338 & $-.668-$ & 1 & & & & & & & & & & & & & 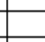 \\
\hline \begin{tabular}{|l|l|} 
TSS \\
Sy3
\end{tabular} & $\begin{array}{l}.486 \\
.0196\end{array}$ & -229. & $\frac{.218}{514}$ & $\frac{208}{600^{\circ}}$ & $\frac{1}{137}$ & & & & & & & & & & & & E \\
\hline $\begin{array}{l}\mathrm{NH} 3 \\
\mathrm{COD}\end{array}$ & .291 & . $.0344^{-684^{\circ}}$ & - $-.514-$ & $\frac{694^{\circ}}{.434}$ & $\frac{.137}{209}$ & $\frac{1}{.394}$ & 1 & & & & & & & & & & 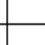 \\
\hline $\begin{array}{l}\text { COD } \\
\text { BOD }\end{array}$ & $\frac{.20-}{248}$ & $\begin{array}{l}.0 .024 \\
-.024 \\
\end{array}$ & $\begin{array}{l}.128 \\
.128\end{array}$ & $\begin{array}{l}.2454 \\
.297 \\
\end{array}$ & 2.231 & $\frac{.944}{-.141}$ & $\frac{1}{21}$ & 1 & & & & & & & & & $\square$ \\
\hline $\begin{array}{l}\text { Hardness } \\
\text { The }\end{array}$ & $-.501-$ & $-458-$ & $\frac{.884^{* *^{*}}}{747^{\circ}}$ & $\frac{-.583}{.169}$ & $\frac{211}{024}$ & $\frac{-.34}{.12}$ & 27 & $\frac{-.13}{21}$ & $\frac{1}{78^{n}}$ & & & & & & & & E \\
\hline 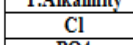 & -357. & -344 & $.863^{* 0}$ & . & . .349 & -.575 & .43 & .006 & $.786^{\prime \prime}$ & .383 & 1 & & & & & & 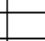 \\
\hline $\begin{array}{l}\text { P04 } \\
y^{2}\end{array}$ & $8.852^{* *}$ & $6.647^{*}$ & - & 631 & .170 & .392 & -48 & .258 & $-6.696^{\circ}$ & - & - -534 & & & & & & 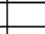 \\
\hline N03 & $-.702^{*}$ & $-.726^{\circ}$ & $897^{* 0}$ & .584 & .019 & -.457 & .578 & .152 & $.828^{* \prime}$ & $822^{* \prime}$ & .628 & $-.821^{*}$ & 1 & & & & 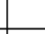 \\
\hline$\frac{\mathrm{NO2}}{\mathrm{Si}}$ & - .682. & 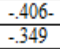 & $\begin{array}{l}.780^{-1} \\
.367\end{array}$ & . .420. & - $-\frac{-21}{458}$ & $\frac{-.32}{.01}$ & $\begin{array}{l}.41 \\
.52\end{array}$ & $\frac{.282}{.660^{\circ}}$ & $.7 .09^{\circ}$ & $\frac{.852^{-*}}{269}$ & $\begin{array}{l}.484 \\
.196\end{array}$ & 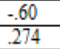 & $\begin{array}{l}.842^{-1} \\
.199\end{array}$ & $\frac{1}{253}$ & 1 & & 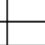 \\
\hline S04 & .462 & $\begin{array}{l}-4944 \\
-600\end{array}$ & $.889^{* \prime \prime}$ & $\frac{.662}{-620}$ & $\frac{.320}{30}$ &.-421 & .60 & .25 & $.741^{\circ}$ & $\frac{.521}{107}$ & $.869^{* *}$ & -469 & $.728^{*}$ & $.675^{*}$ & .477 & 1 & . \\
\hline $\begin{array}{l}\text { Temp. } \\
\text { Concraticic }\end{array}$ & $-100-$ & $-696^{\circ}$ & & .340 & .396 & $-350-$ & .425 & .134 & & .107 & .440 & - $-418-$ & .460 & - $-.013-$ & .235 & & 11 \\
\hline
\end{tabular}

\section{CONCLUSION}

Monitoring the fresh water regularly can help to identify the sources and fates of contaminants. This would mitigate outbreak of health disorders and the detrimental impacts on the aquatic ecosystem. The present paper presented comprehensive water quality information of Mahmoudia canal and analyzed sixteen physicochemical parameters at the eight sampling stations during the year 2018 using multivariate statistical techniques. The concentrations of some heavy metals were investigated at most sites of the water were free from toxic metals and below the detection limits except Aluminum ions exceeded the background level with values 0.395 and 0.355 $\mathrm{mg} / \mathrm{L}$, in both town of Kafr El Dawar and town of Abou Hommos sites. The concentration of pesticides was undetectable indicating that the canal is free from them and hence safe for drinking purposes. Water Quality Index (WQI) was calculated for all sampling sites in four seasons. A correlation matrix assessment was carried out to check the significant relationship among biological and physicochemical parameters.

\section{REFERENCES}

Abdar, M. R. (2013). Physico-chemical characteristics and phytoplankton of morna lake, shirala (M.S.) India. Inter. Quar. J. Bio \& Lif. Sci., 1(2): 1-7.

Abdelmongy, A. S. and El-Moselhy, K. M. (2015). Seasonal variations of the physical and chemical properties of seawater at the northern Red Sea, Egypt. Op. J. Oce \& Coas. Sci., 2:1-16.

Abdullah, A. and Hussona, S. E. (2014). Water quality assessment of Mahmoudia canal in northern west of Egypt. J. Pollut. Eff \& Cont., 2:2-10.

Aboul Ezz, S. M.; Heneash, A. M. M. and Gharib, S. M. (2014). Variability of spatial and temporal distribution of zooplankton communities at matrouh beaches, south-eastern Mediterranean Sea, Egypt. Egy. J. Aqu. Res., 40:283-290.

Abukila, A. (2012). Assessment of natural self-restoration of the water of AlMahmoudia canal, western part of Nile delta, Egypt. J. Irrig \& Drain. Sys. Eng., $1(3): 1-10$. 
Aggarwal, R. and Arora, S. (2012). A study of water quality of kaushalya river in the submountaneous shivalik region. Int. J. Sci \& Techno. Res.,8: 52-68.

Al-Qutob, M.; Hase, C.; Tilzer, M. M. and Lazar, B. (2002). Phytoplankton drives nitrite dynamics in the gulf of Aqaba, Red Sea. Mar. Eco. Pro. Ser., 239: 233239.

APHA. (1999). Standard methods. 20th edition. American public health association, Washington, DC, USA.

APHA-AWWA-WPCF. (2005). Standard methods for the examination of water and wastewater, (21st edn) american public health association, american water works association, water pollution control federation, U.S.A.

Batabyal, A. K. and Chakraborty, S. (2015). Hydro geochemistry and water quality index in the assessment of groundwater quality for drinking uses. Wat. Environ. Res., 5: 607-617.

Domingo-Ferrer, J. (1996). Heavy metal pollution in coastal red sea waters. Symp. on Red Sea Mar. Environ. Jeddah., 7: 67-74.

Egyptian Environmental Affairs Agency (EEAA). (2002). Water quality data of the Nile River, Egypt.

EWQS (Egyptian drinking water quality standards). (2007). Ministry of Health, population decision number, 458.

Galal, N. M. (1983). Determination of pesticides in Alexandria drinking water. Master thesis, High Institute of Public Health, Alexandria University, Egypt.

Guerrero, M. A. and Jones, R. D. (1996). Photoinhibition of marine nitrifying bacteria, I. Wave length dependent response. Mar. Eco. Prog. Ser., 141:183-192.

Heneash, A. M. (2015). Assessment of water quality of unfertilized fish farm using zooplankton diversity index and some a biotic factors. Egy. J. Aqua. Bio \& Fish., 19(3):35-44.

Heneash, A. M. M.; Tadrose, H. R. Z.; Hussein, M. M. A.; Hamdona, S. K.; abdelAziz N. and Gharib S. M. (2015). Potential effects of abiotic factors on the abundance and distribution of the plankton in the western harbour, south-eastern Mediterranean Sea, Egypt. Oceanologia., 57:61-70.

Koning, N. and Roos, J. C. (1999). The continued influence of organic pollution on the water quality of the turbid modder river. Wat. S. Afr., 25:285-292.

Martynova, D. M. and Gordeeva, A.V. (2010). Light-dependent behavior of abundant zooplankton species in the white sea. J. Plan. Res., 32(4): 441-456.

Nassar, M. Z. and Hamed, M. A. (2003). Phtoplankton standing crop and species diversity in relation to some water characteristics of Suez Bay (Red Sea), Egypt. Egy. J. Aqua. Bio \& Fish., 7: 25-48.

Shaaban, S.; Deyab, M and Mofeed, J. (2004). Phycological assessment of water quality of river Nile delta -Egypt. Egy. J. Phycol., 5:

Shama, S. A.; Goher, M. E.; Abdo, M. H.; Kaial, S. M. and Ahmed, A. A. (2011). Physico-chemical characteristics and heavy metal contents in water of Wadi ElRayan lakes, western desert, Egypt. Egypt. J. Aquat. Biol \& Fish., 15: 225-240.

Shinde, S. E.; Pathan, T. S.; Raut, K. S. and Sonawane, D. L. (2011). Studies on the physico-chemical parameters and correlation coefficient of harsool-savangi dam, district aurangabad, India. Mid. Eas. J.Sci. Res., 8(3): 544-554.

Springer, A. and Skrzypczak, A. (2015). The effect of above - water artificial light on the zooplankton abundance in cages for fish rearing. Pol. J. Natur. Sc., 30: 379-387. 
Taha, A. A.; El-Mahmoudi, A. S. and El-Haddad, I. M. (2004). Pollution sources and related environmental impacts in the new communities' southeast Nile delta, Egypt. Emir. J. Eng. Res., 9: 35-49.

Tokatlı, C.; Gürbüz, E. and Arslan, N. (2013). Socio Ecological and economical interactions between local public (Enez) with the gala lake national park (Edirne, Turkey). Gabrovo, Bulgaria,383-386.

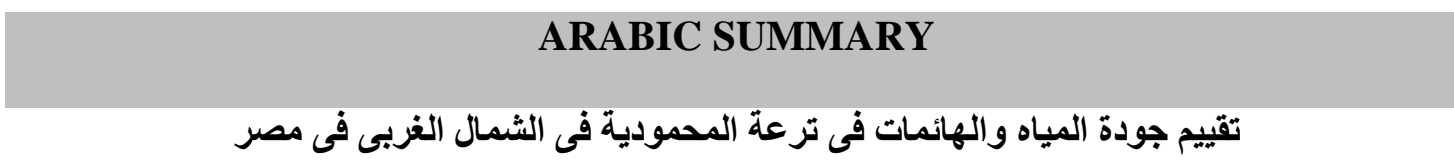

محمد ممدوح الققى ، أحمد عيد البرل* ، أحمد مبرولك حنيش ، حمدى ابوطالب ، محسن يوسف عمر

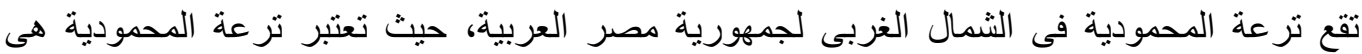

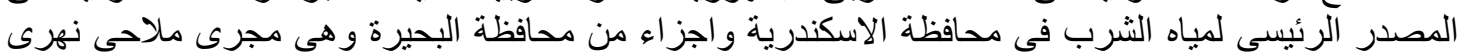

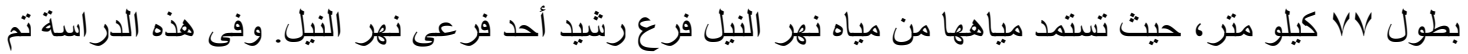

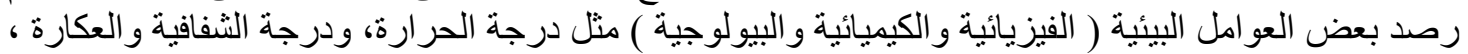
ودرجة الأس الهيدروجينى، وكذلك درجة التوصيل الكهربى، ونركيز الأكسجين الذائب فى المياه، ونركيز الاكسجين المستهلك بيولوجيا وكيميائيا، وتركيز الأمونيا، وتركيز الأملاح الكلية الذائبة ،وتركيز المين المواد التيز العالقة، و و النيتريت و النترات و النيتروجين و الفوسفات وأخيرا بعض العناصر الثقيلة والمبيدات. كما تم تقدير كل من المحصول القائم لكل من الهائمات النباتية والحيوانية التية فى عشر محطات بطول نر عة المحمودية خلال مواسم عام

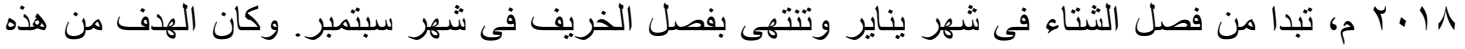
الدر اسة هو الوقوف على التغيير ات في فو فئية المياه وكذلك در اسة العلاقات بين المتغير ات الفيزيائية و الكيميائية

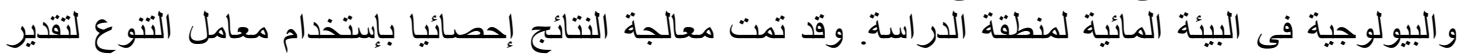

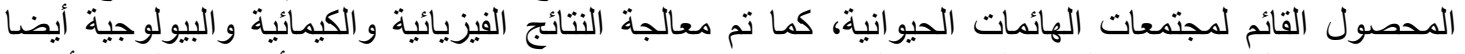

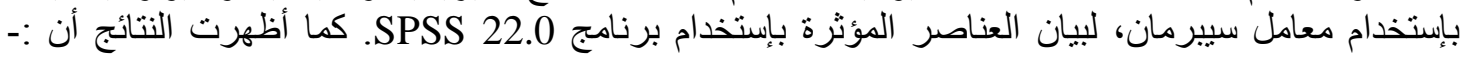

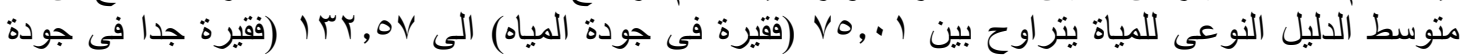

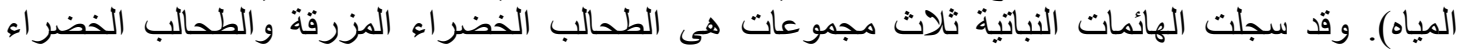

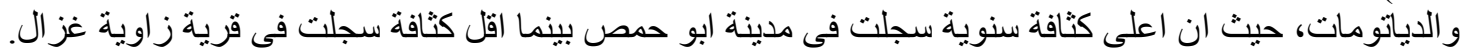

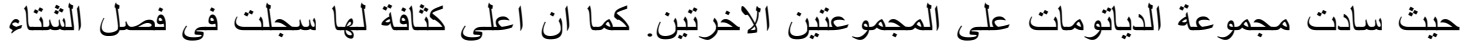

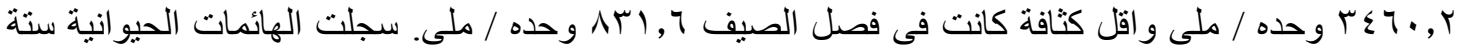

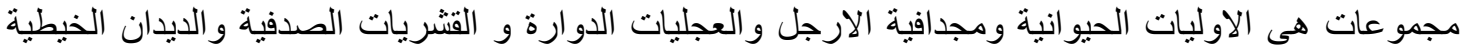

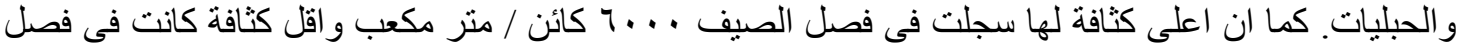

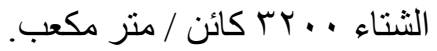

